\title{
Prevalence and determinants of tobacco use amongst South African adults with mental illness in the Eastern Cape
}

\begin{tabular}{|c|c|}
\hline \multicolumn{2}{|c|}{$\begin{array}{l}\text { Authors: } \\
\text { Linda K. Tindimwebwa }{ }^{1,2} \\
\text { Anthony I. Ajayi }{ }^{3} \text { (0) } \\
\text { Oladele V. Adeniyiji, }\end{array}$} \\
\hline $\begin{array}{l}\text { Affiliations: } \\
{ }^{1} \text { Department } \\
\text { Faculty of Hea } \\
\text { Walter Sisulu } \\
\text { East London, }\end{array}$ & $\begin{array}{l}\text { of Psychiatry, } \\
\text { Ith Sciences, } \\
\text { University, } \\
\text { jouth Africa }\end{array}$ \\
\hline $\begin{array}{l}{ }^{2} \text { Cecilia Makiu } \\
\text { East London, }\end{array}$ & $\begin{array}{l}\text { lane Hospital, } \\
\text { south Africa }\end{array}$ \\
\hline $\begin{array}{l}{ }^{3} \text { Population D } \\
\text { Sexual and Re } \\
\text { Health Resear } \\
\text { Population an } \\
\text { Research Cen } \\
\text { Nairobi, Keny }\end{array}$ & $\begin{array}{l}\text { promics and } \\
\text { productive } \\
\text { ch, African } \\
\text { d Health } \\
\text { re, }\end{array}$ \\
\hline $\begin{array}{l}{ }^{4} \text { Department } \\
\text { Medicine, Fac } \\
\text { Health Scienc } \\
\text { Sisulu Univers } \\
\text { London, Sout }\end{array}$ & $\begin{array}{l}\text { Family } \\
\text { ulty of } \\
\text { es, Walter } \\
\text { ity, East } \\
\text { Africa }\end{array}$ \\
\hline $\begin{array}{l}\text { Correspondin } \\
\text { Linda Tindimv } \\
\text { lintin@hotma }\end{array}$ & $\begin{array}{l}\text { g author: } \\
\text { ebwa, } \\
\text { il.com }\end{array}$ \\
\hline $\begin{array}{l}\text { Dates: } \\
\text { Received: } 27 \$ \\
\text { Accepted: } 16 \\
\text { Published: } 14\end{array}$ & $\begin{array}{l}\text { ept. } 2020 \\
\text { Apr. } 2021 \\
\text { June } 2021\end{array}$ \\
\hline $\begin{array}{l}\text { How to cite th } \\
\text { Tindimwebwa } \\
\text { Adeniyi OV. Pr } \\
\text { determinants } \\
\text { amongst Sout } \\
\text { with mental il } \\
\text { Eastern Cape. } \\
\text { Psychiat. 2021 } \\
\text { https://doi.or } \\
\text { sajpsychiatry. }\end{array}$ & $\begin{array}{l}\text { is article: } \\
\text { LK, Ajayi Al, } \\
\text { evalence and } \\
\text { of tobacco use } \\
\text { h African adults } \\
\text { ness in the } \\
\text { S Afr J } \\
; 27(0) \text {, a1637. } \\
\text { /10.4102/ } \\
270.1637\end{array}$ \\
\hline $\begin{array}{l}\text { Copyright: } \\
\text { @ 2021. The } \\
\text { Licensee: AOS } \\
\text { is licensed un } \\
\text { Creative Com } \\
\text { Attribution Lic }\end{array}$ & $\begin{array}{l}\text { uthors. } \\
\text { IS. This work } \\
\text { der the } \\
\text { nons } \\
\text { ense. }\end{array}$ \\
\hline 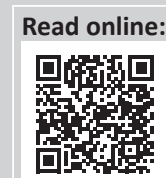 & $\begin{array}{l}\text { Scan this QR } \\
\text { code with your } \\
\text { smart phone or } \\
\text { mobile device } \\
\text { to read online. }\end{array}$ \\
\hline
\end{tabular}

Background: Given the physical and mental health consequences of tobacco use amongst individuals with mental illness, it was imperative to assess the burden of tobacco use in this population.

Aim: This study examined the patterns and factors associated with tobacco use in individuals attending the outpatient unit.

Setting: Cecilia Makiwane Hospital Mental Health Department in Eastern Cape province, South Africa.

Methods: Lifetime (ever use) use and current use of any tobacco products were examined in a cross-sectional study of 390 individuals between March and June 2020. A logistic regression was fitted to determine the correlates of lifetime and current use of any tobacco products.

Results: The rates of ever use and current use of tobacco products were $59.4 \%$ and $44.6 \%$, respectively. Of the participants interviewed, lifetime tobacco use was more prevalent amongst individuals with schizophrenia (67.9\%) and cannabis-induced disorders (97.3\%) and lower in those with major depressive disorders (36.1\%) and bipolar and related disorders (43.5\%). Men were six times more likely to have ever used or currently use tobacco products in comparison to women. Also, those who had a salaried job or owned a business were over three times more likely to have ever used or currently use tobacco products compared with those receiving government social grants.

Conclusions: The prevalence of tobacco use in this study was significantly higher than the general population in the Eastern Cape. Therefore, smoking prevention and cessation interventions targeted at the general population should target this often neglected sub-population in the region.

Keywords: Eastern Cape province; mental health users; mental illness; South Africa; tobacco use.

\section{Introduction}

Tobacco use is a leading cause of morbidity and mortality worldwide, with an estimated 6 million deaths per year. ${ }^{1}$ Besides lung cancer, it is a significant risk factor for various respiratory illnesses, cardiovascular diseases and cerebrovascular accidents. ${ }^{1}$ According to the World Health Organisation (WHO), more than 1.1 billion people (20.2\%) used tobacco globally. ${ }^{2}$ Of these, 66 million were in Africa, with a prevalence of $10.0 \%$.

According to the National Department of Health, South Africa, tobacco use prevalence was 37\% and $7 \%$ for men and women, respectively. ${ }^{3}$ However, there are variations in the prevalence of tobacco use according to gender, age and geographical location. Reddy et al. ${ }^{4}$ reported a prevalence of tobacco use of $17.6 \%$ amongst South African adults, with variations across provinces: Western Cape, Northern Cape, Eastern Cape and Free State had the highest prevalence at 32.9\%, 31.2\%, $31.4 \%$ and $27.4 \%$, respectively. The study by Owolabi et al., ${ }^{5}$ however, reported an even lower prevalence of $15 \%$ in Buffalo City Metropolitan Municipality (BCMM) in the Eastern Cape. ${ }^{5}$ However, the majority of the participants in their study were women. Globally, the low-income countries such as Haiti, Burkina Fasso and Bangladesh, respectively, reported current use of tobacco amongst the general population as $8.3 \%, 16.0 \%$ and $39.1 \%$. In high-income nations 
such as Singapore, Canada, Seychelles and Austria, the figures reported were $16.5 \%, 17.5 \%, 21.1 \%$ and $29.1 \%$, respectively (World Bank Group). ${ }^{6}$

Although several prevalence studies have been carried out on tobacco use in South Africa, ${ }^{3,4,5}$ it should be noted that these studies did not include individuals with mental illness. This identified gap in the overall understanding of tobacco use in this sub-population and the country needs to be addressed. Such data will help in designing user-specific interventions aimed at curbing tobacco use amongst individuals with mental illness.

Evidence suggests that individuals with long-standing mental illnesses are more likely to use tobacco products than the general population. ${ }^{7}$ Some studies have estimated up to a fivefold increase in the use of tobacco products in people with depression, anxiety, schizophrenia, eating disorders and attention deficit hyperactivity disorder (ADHD) ${ }^{8,9,10,11}$

Several theories have been advanced to explain the link between tobacco use and mental illness. There is also a bidirectional relationship between tobacco use and psychiatric symptoms..$^{12}$ There is evidence of the association between tobacco use and changes in neural circuits and brain structures that are involved in psychiatric disorders. ${ }^{8}$ Individuals with mental illness tend to self-medicate with tobacco to ameliorate the symptoms. ${ }^{13}$ Conversely, studies have indicated that smoking itself may cause depression and anxiety. ${ }^{14,15}$

Tobacco use can also be a gateway drug to further substance use. ${ }^{16}$ Similarly, evidence suggests that second-hand smoke could lead to the development of generalised anxiety disorder, depression, conduct disorder and ADHD. ${ }^{17,18}$

Of particular importance in individuals with mental illness who use tobacco, particularly smokers, are the drug interactions. Some drugs (e.g. antidepressants, antipsychotics, mood stabilisers and sedative or hypnotics) used for treating mental illness are metabolised by hepatic cytochrome (CYP) $1 \mathrm{~A} 2$ enzymes. ${ }^{19}$ Polycyclic aromatic hydrocarbons in cigarette smoke have been shown to induce CYP1A2 enzymes in heavy or moderate smokers. This enzyme induction impacts drug metabolism, leading to smokers requiring higher doses of medication to achieve therapeutic effects, and consequently increased risk of adverse effects. . $^{10,20,21,22}$

Given the physical and mental health consequences of tobacco use amongst individuals with mental illness, it is therefore imperative to assess the burden of tobacco use in this population. More so, most of the smoking cessation programmes tend to focus on the general population and, thus, neglect individuals with mental illness. ${ }^{23}$ There is little or no research on tobacco use in individuals with mental illness in South Africa, especially in the Eastern Cape province. This important data might guide the provincial health directorate in crafting user-specific interventions for this sub-population.

The objectives of this study were thus:

1. To describe the rate and pattern of tobacco use amongst individuals with mental illness attending the outpatient unit of a Mental Health Department in the Eastern Cape.

2. To examine the factors associated with tobacco use in the cohort.

\section{Methods \\ Study design and setting}

This cross-sectional study was conducted between March and June 2020 at the outpatient unit of a Mental Health Department in the Eastern Cape. This department is affiliated with a large university for the training of both undergraduate and postgraduate students in the Eastern Cape. It offers mental healthcare services to the entire BCMM and Amathole district in the Eastern Cape province, which has a combined population of 1674637 people living in it. ${ }^{23}$ It comprises inpatient and outpatient units of 25 beds each. The outpatient unit sees between 13000 and 15000 patients per year. The facility users reflect the racial distribution of the entire BCMM: black people (85.1\%), white people $(7.7 \%)$, mixed-race people $(6 \%)$, Indians $(0.8 \%)$ and others $(0.3 \%)$, and the predominant language spoken is isiXhosa. ${ }^{24}$

\section{Participants and sample size}

Using Cochran's formula ${ }^{25}$ for cross-sectional study at a confidence level of $95 \%$, a precision level of $\pm 5 \%$, tobacco use prevalence of $50 \%$ and anticipated missing responses of $5 \%$, the sample size was estimated as 390 .

Sample Size $(N)=Z_{1-} \alpha_{/ 2}{ }^{2} p(1-p) / d^{2}$

where $z_{1-} \alpha_{/ 2}$ is the standard normal variate at 1.96 .

$P$ is the expected proportion of patients with dual diagnosis based on previous studies, ${ }^{26}$ and observation of patients admitted in the wards at Cecilia Makiwane Hospital Mental Health Unit (CMHMHU), at $50 \%$, which is equal to 0.5 .

$d=0.05$

Sample size $(N)=384.16$, which was increased to 390 .

Individuals attending the outpatient unit of the Mental Health Department were considered eligible for the study. Participants were included if they were 18 years and above, had been on treatment for the underlying mental illness for at least 1 year and were clinically stable to be interviewed for the study. Based on history taking and mental state examination, the attending doctors on each day carried out a risk assessment on patients. Individuals who posed a threat 
to themselves, others and/or property were managed according to the protocol of the department and were excluded from the study. Eligible participants were recruited consecutively after being in consultation with the attending doctor each day. The attending doctor administered the questionnaire and also reviewed the medical records of the participants.

\section{Study instrument}

A structured questionnaire comprising three sections was compiled. The sections were as follows: demographic data, use of tobacco products and other substances and the current diagnosis of mental illness, using categories from the Diagnostic and Statistical Manual of Mental Disorders, 5th Edition (DSM-5). ${ }^{27}$

\section{Validity and reliability}

To ensure the construct and face validity of the study instrument, relevant items from the pre-validated WHO STEPwise $^{28}$ and National Institute on Drug Abuse (NIDA) ${ }^{29}$ questionnaires were selected and collated.

Although some of these validated questionniares have been used successfully in South Africa, ${ }^{5}$ we further tested the validity and reliability of the adapted instrument in this special population through a pilot study with 10 patients in the setting. Adjustments were made using clinician feedback and participant responses.

Specifically, we realised from the pilot study that only medical doctors (excluding intern doctors) were needed for risk assesment and recruitment of stable patients for this study. The current use of cigarette smoking was defined as smoking in the past 12 months. However, the pilot study's results were excluded from the final analysis.

\section{Study procedure}

Group information detailing the purpose and process of the study was provided to patients by the principal investigator before their consultations. Doctors were trained by the principal investigator on the selection criteria and how to administer the questionnaire after consultation with the participants. The main doctor in the outpatient clinic for each day administered the questionnaire (after the consultation) and also reviewed the clinical notes for additional information. Given that this study was carried out during the first wave of coronavirus disease 2019 (COVID-19) with the nation's lockdown, the data collection lasted for 4 months - from March 2020 to June 2020 - and was mostly carried out during weekdays.

\section{Main outcome measure}

Tobacco use was defined as the use of any products: cigarettes, cigars, loose tobacco rolled in paper or smoked in a pipe, chewable tobacco and inhaled snuff. Evidence suggests that there is no safe limit for smoking in any individual. ${ }^{30,31}$ Hence, any form or amount of tobacco use is considered an unhealthy lifestyle behaviour. This was categorised as self-reported current use (in the previous year) and ever use of any tobacco products. In addition to self-reported tobacco usage, clinical notes of each participant were reviewed to validate the responses given. Where there were discrepancies, the participants' clinical notes were taken as the true status of tobacco use.

\section{Covariates}

Relevant demographic characteristics such as age, sex, race, level of education, marital status, employment, monthly income and area of residence were obtained through interviews. Demographic characteristics were categorised according to a similar report from the general population in the same setting. ${ }^{5}$ Participants' ages (in years) were categorised as follows: 18-25, 26-35, 36-45, 46-55, 56-65 and 66 years or older. Socio-economic status followed the pattern described by Geyer et al. ${ }^{32}$ : level of education, occupation and income. The highest level of education attained by the participants was categorised as follows: none, grades $1-7$, grades $8-12$ and tertiary.

Household monthly income in rands was categorised as follows: none, R150-R2000, R2001-R5000 and R5001 or more. Employment status was categorised as none, having a job or business and social assistance (disability grant, child grant, pension). Participants were considered unemployed if they were unemployed in the formal or informal sector.

\section{Statistical analysis}

Data were entered into an Excel spreadsheet and doublechecked for accuracy. Analysis was conducted using the IBM Statistical Package for Social Sciences Version 24.0 for Windows (IBM Corp. Armonk, New York, the United States of America). Categorical variables were reported as frequencies $(n)$ and percentages (\%), whilst continuous variables were reported as means ( \pm standard deviation). Simple descriptive statistics were used to summarise the socio-demographic characteristics of the participants. Bivariate analysis was conducted to examine the associations between background characteristics and tobacco use. Multivariate logistic regression analysis was used to examine the correlates of tobacco use. A $p$-value of $<0.05$ was considered to be statistically significant.

\section{Ethical considerations}

Ethical approval was obtained from the Research Ethics Committee of the affiliated university in the Eastern Cape (Reference number 093/2019). Permission was obtained from the Eastern Cape Department of Health, and the 
clinical governance of the research site. An information sheet (written in English and Xhosa) detailing the purpose and procedure of the study was given to each participant. Each participant or legal guardian (if the participant was unable to consent because of diminished capacity in individuals with neurocognitive disoders and intellectual impairment) gave written informed consent for voluntary participation in the study. This decision was made by the attending doctor. The study followed the Helsinki Declaration on human and animal research guidelines. Participants' rights to privacy, confidentiality and anonymity were respected during and after the study. Unique code identifiers were assigned to each participant in order to maintain their anonymity. All hard copies of materials used in the study were locked in a protected cabinet, whilst soft copies were password protected.

\section{Results}

\section{Socio-demographic characteristics of the study participants}

Most of the participants were men (59.5\%), black (87.2\%) and single $(74.9 \%)$; had an education level of grades $8-12$ (57.2\%); and were between 46 and 55 years of age (27.2\%). In addition, $81 \%$ were unemployed, $67.4 \%$ had social assistance (disability grants, pensions and child-care grants) as their source of income and $46.9 \%$ had a combined household income of R2000-R5001 per month. The majority of participants lived in urban areas (83.6\%) with their families (84.9\%) (Table 1).

\section{Tobacco use}

Of the participants interviewed $(N=390), 54.9 \%$ reported having ever used and $44.6 \%$ reported current use of tobacco products. In the bivariate analysis, age, gender and source of income were significantly associated with having ever used and current use of tobacco products $(p<0.05)$ (Table 2).

Of the participants interviewed $(N=390)$, lifetime tobacco use was more prevalent amongst individuals with schizophrenia (67.9\%) and cannabis-induced disorders $(97.3 \%)$ and was lower in those with major depressive disorders $(36.1 \%)$ and bipolar and related disorders $(43.5 \%)$.

Current tobacco use was higher amongst individuals with schizophrenia (58.5\%) and cannabis-induced disorders $(86.7 \%)$ and was lower amongst those with major depressive disorder (49.1\%) and bipolar and related disorders $(27.5 \%)$. The difference was statistically significant $(p<0.05)$ (Table 3$)$.

\section{Multivariable findings}

In the unadjusted (logistic regression model) analysis, male gender, younger age, having grade 8-12 level of
TABLE 1: Socio-demographic characteristics of the study participants.

\begin{tabular}{|c|c|c|}
\hline Variables & Frequency & $\%$ \\
\hline \multicolumn{3}{|l|}{ Gender } \\
\hline Male & 232 & 59.5 \\
\hline Female & 158 & 40.5 \\
\hline \multicolumn{3}{|l|}{ Age (years) } \\
\hline $18-25$ & 37 & 9.5 \\
\hline $26-35$ & 87 & 22.3 \\
\hline $36-45$ & 90 & 23.1 \\
\hline $46-55$ & 106 & 27.2 \\
\hline $56-65$ & 48 & 12.3 \\
\hline 66 and above & 22 & 5.6 \\
\hline \multicolumn{3}{|l|}{ Race } \\
\hline Black people & 340 & 87.2 \\
\hline White people & 34 & 8.7 \\
\hline Mixed race people & 14 & 3.6 \\
\hline Indian or Asian people & 2 & 0.5 \\
\hline \multicolumn{3}{|l|}{ Education } \\
\hline No formal education & 13 & 3.3 \\
\hline Grades $1-7$ & 89 & 22.8 \\
\hline Grades 8-12 & 223 & 57.2 \\
\hline Tertiary & 65 & 16.7 \\
\hline \multicolumn{3}{|l|}{ Marital status } \\
\hline Single & 292 & 74.9 \\
\hline Married & 37 & 9.5 \\
\hline Divorced or separated & 25 & 6.4 \\
\hline Widowed & 20 & 5.1 \\
\hline Cohabiting & 16 & 4.1 \\
\hline \multicolumn{3}{|l|}{ Employment } \\
\hline Employed & 33 & 8.5 \\
\hline Unemployed & 316 & 81.0 \\
\hline Student & 11 & 2.8 \\
\hline Retired & 30 & 7.7 \\
\hline \multicolumn{3}{|l|}{ Household income (in rand) } \\
\hline None & 24 & 6.2 \\
\hline $150-2000$ & 114 & 29.2 \\
\hline $2001-5000$ & 183 & 46.9 \\
\hline $5001 \mathrm{R}$ and over & 69 & 17.7 \\
\hline \multicolumn{3}{|l|}{ Source of income } \\
\hline None & 94 & 24.1 \\
\hline Job or business & 33 & 8.5 \\
\hline Social assistance & 263 & 67.4 \\
\hline \multicolumn{3}{|l|}{ Place of residence } \\
\hline Rural & 64 & 16.4 \\
\hline Urban & 326 & 83.6 \\
\hline \multicolumn{3}{|l|}{ Living arrangement } \\
\hline Living alone & 19 & 4.9 \\
\hline Living with friends & 18 & 4.6 \\
\hline Living with family (nuclear or extended) & 331 & 84.9 \\
\hline Living with partner or spouse only & 22 & 5.6 \\
\hline
\end{tabular}

education and source of income were significantly associated with a higher likelihood of having ever used tobacco products. However, after adjusting for relevant covariates, only male gender, being unemployed and having a salaried job or owning a business were significantly associated with a higher odds of having ever used tobacco products. Men were six times more likely to have ever used tobacco products in comparison to women. Also, those who had a salaried job or owned a business were over three times more likely to have ever used 
TABLE 2: Association between background characteristics and tobacco use.

\begin{tabular}{|c|c|c|c|c|c|c|}
\hline \multirow[t]{3}{*}{ Variables } & \multicolumn{3}{|c|}{ Ever used tobacco products } & \multicolumn{3}{|c|}{ Tobacco use in the previous year } \\
\hline & \multicolumn{2}{|c|}{ Yes } & \multirow[t]{2}{*}{$p$} & \multicolumn{2}{|c|}{ Yes } & \multirow[t]{2}{*}{$p$} \\
\hline & $n$ & $\%$ & & $n$ & $\%$ & \\
\hline All & 214 & 54.9 & & 174 & 44.6 & \\
\hline \multicolumn{7}{|l|}{ Gender } \\
\hline Male & 165 & 71.1 & $<0.001$ & 141 & 60.8 & $<0.001$ \\
\hline Female & 49 & 31.0 & & 33 & 20.9 & \\
\hline \multicolumn{7}{|l|}{ Age (year) } \\
\hline $18-35$ & 71 & 57.3 & 0.025 & 59 & 47.6 & 0.002 \\
\hline $36-45$ & 54 & 60.0 & & 46 & 51.1 & \\
\hline $46-55$ & 62 & 58.5 & & 52 & 49.1 & \\
\hline 56 and above & 27 & 38.6 & & 17 & 24.3 & \\
\hline \multicolumn{7}{|l|}{ Education } \\
\hline No formal education and up to Grade 7 & 53 & 52.0 & 0.091 & 46 & 45.1 & 0.147 \\
\hline Grades 8-12 & 132 & 59.2 & & 106 & 47.5 & \\
\hline \multicolumn{7}{|l|}{ Marital status } \\
\hline Single & 182 & 54.0 & 0.237 & 145 & 43.0 & 0.075 \\
\hline Married or cohabiting & 32 & 60.4 & & 29 & 54.7 & \\
\hline \multicolumn{7}{|l|}{ Employment } \\
\hline Employed & 22 & 66.7 & 0.096 & 17 & 51.5 & 0.096 \\
\hline Unemployed & 176 & 55.7 & & 145 & 45.9 & \\
\hline Student & 5 & 45.5 & & 5 & 45.5 & \\
\hline Retired & 11 & 36.7 & & 7 & 23.3 & \\
\hline \multicolumn{7}{|l|}{ Household income (in rand) } \\
\hline $0-2000$ & 82 & 59.4 & 0.205 & 66 & 47.8 & 0.580 \\
\hline $2001-5000$ & 100 & 54.6 & & 80 & 43.7 & \\
\hline 5001 and over & 32 & 46.4 & & 28 & 40.6 & \\
\hline \multicolumn{7}{|l|}{ Source of income } \\
\hline None & 64 & 68.1 & 0.001 & 50 & 53.2 & 0.025 \\
\hline Job or business & 23 & 69.7 & & 19 & 57.6 & \\
\hline Rural & 33 & 51.6 & 0.328 & 28 & 43.8 & 0.495 \\
\hline Urban & 181 & 55.5 & & 146 & 44.8 & \\
\hline \multicolumn{7}{|l|}{ Living arrangement } \\
\hline Living alone & 13 & 68.4 & 0.303 & 9 & 47.4 & 0.554 \\
\hline Living with friends & 12 & 66.7 & & 8 & 44.4 & \\
\hline Living with family (nuclear and/or extended) & 175 & 52.9 & & 144 & 43.5 & \\
\hline Living with partner or spouse only & 14 & 63.6 & & 13 & 59.1 & \\
\hline
\end{tabular}

TABLE 3: Association between common mental illnesses and tobacco use.

\begin{tabular}{|c|c|c|c|c|}
\hline \multirow[t]{2}{*}{ Variables } & \multicolumn{2}{|c|}{ Life time tobacco use } & \multicolumn{2}{|c|}{ Previous year use } \\
\hline & $n$ & $\%$ & $n$ & $\%$ \\
\hline \multicolumn{5}{|c|}{$\begin{array}{l}\text { Major depressive } \\
\text { symptoms }\end{array}$} \\
\hline Yes & 26 & 36.1 & 18 & 25.0 \\
\hline No & 188 & $59.12 * *$ & 156 & $49.1 * *$ \\
\hline \multicolumn{5}{|c|}{ Bipolar related } \\
\hline Yes & 30 & 43.5 & 19 & 27.5 \\
\hline No & 184 & $57.3^{*}$ & 155 & $48.3^{*}$ \\
\hline \multicolumn{5}{|c|}{ Schizophrenia } \\
\hline Yes & 108 & $67.9 * *$ & 93 & $58.5^{* *}$ \\
\hline No & 106 & 45.9 & 81 & 35.1 \\
\hline \multicolumn{5}{|c|}{ Other psychotic disorders } \\
\hline Yes & 10 & 38.5 & 9 & 34.6 \\
\hline No & 204 & 56.0 & 165 & 45.3 \\
\hline \multicolumn{5}{|c|}{ Alcohol-related disorders } \\
\hline Yes & 26 & 66.7 & 22 & 56.4 \\
\hline No & 188 & 53.6 & 152 & 43.3 \\
\hline \multicolumn{5}{|c|}{ Cannabis-related disorders } \\
\hline Yes & 73 & $97.3^{*}$ & 65 & $86.7^{* *}$ \\
\hline No & 141 & 44.8 & 109 & 34.6 \\
\hline
\end{tabular}

tobacco products compared with those receiving government social grants.

Similar findings emerged regarding tobacco use in the previous year (current use). Male gender, single marital status, being employed and aged 36-55 years were significantly associated with current use of tobacco products in the unadjusted model. In the adjusted model, men were six times more likely to have used any tobacco products in the previous year compared with women. Individuals aged 36-55 years were twice more likely to have used tobacco products in the previous year compared with those aged 56 years and above, after adjusting for other covariates. Also, single individuals were $58 \%$ less likely to have used any tobacco products in the previous year compared with married individuals. Those who had a salaried job or owned a business were about three times more likely to have used tobacco products compared with those on social grants (Table 4). 
TABLE 4: Multiple logistic regression analysis showing predictors of tobacco use.

\begin{tabular}{|c|c|c|c|c|c|c|c|c|}
\hline \multirow[t]{3}{*}{ Variables } & \multicolumn{4}{|c|}{ Ever used tobacco products } & \multicolumn{4}{|c|}{ Previous year use of tobacco products } \\
\hline & \multicolumn{2}{|c|}{ Unadjusted } & \multicolumn{2}{|c|}{ Adjusted } & \multicolumn{2}{|c|}{ Unadjusted } & \multicolumn{2}{|c|}{ Adjusted } \\
\hline & OR & $95 \% \mathrm{Cl}$ & OR & $95 \% \mathrm{Cl}$ & OR & $95 \% \mathrm{Cl}$ & OR & $95 \% \mathrm{Cl}$ \\
\hline \multicolumn{9}{|l|}{ Gender } \\
\hline Male & 5.48 & $3.53-8.51 * *$ & 5.67 & $3.49-9.27 * *$ & 5.87 & $3.69-9.35 * *$ & 6.14 & $3.66-10.31 * *$ \\
\hline Female (ref) & 1 & - & 1 & - & 1 & - & 1 & - \\
\hline \multicolumn{9}{|l|}{ Age (year) } \\
\hline $36-45$ & 2.39 & $1.26-4.53^{*}$ & 1.61 & $0.78-3.31$ & 3.26 & $1.64-6.47^{*}$ & 2.42 & $1.13-5.16^{*}$ \\
\hline $46-55$ & 2.24 & $1.21-4.16^{*}$ & 1.68 & $0.84-3.36$ & 3.00 & $1.54-5.84 *$ & 2.24 & $1.07-4.67 *$ \\
\hline 56 and above (ref) & 1 & - & 1 & - & 1 & - & 1 & - \\
\hline \multicolumn{9}{|l|}{ Education } \\
\hline No formal education and up to Grade 7 & 1.34 & $0.72-2.51$ & 1.20 & $0.57-2.54$ & 1.61 & $0.84-3.06$ & 1.49 & $0.70-3.17$ \\
\hline Grades 8-12 & 1.80 & $1.03-3.14^{*}$ & 1.61 & $0.84-3.11$ & 1.77 & $0.99-3.15$ & 1.53 & $0.78-2.98$ \\
\hline Tertiary (ref) & 1 & - & 1 & - & 1 & - & 1 & - \\
\hline Single & 0.77 & $0.43-1.39$ & 0.66 & $0.33-1.31$ & 0.63 & $0.35-1.12$ & 0.42 & $0.21-0.85 *$ \\
\hline Married or co-habiting (ref) & 1 & - & 1 & - & 1 & - & 1 & - \\
\hline \multicolumn{9}{|l|}{ Source of income } \\
\hline Unemployed & 2.29 & $1.39-3.75^{*}$ & 2.17 & $1.22-3.85 *$ & 1.71 & $1.06-2.75 *$ & 1.49 & $0.86-2.59$ \\
\hline Job or business & 2.46 & $1.13-5.38^{*}$ & 3.45 & $1.37-8.67 *$ & 2.04 & $0.98-4.25$ & 2.51 & $1.04-6.05 *$ \\
\hline Social assistance (ref) & 1 & - & 1 & - & 1 & - & 1 & - \\
\hline \multicolumn{9}{|l|}{ Place of residence } \\
\hline Rural & 0.85 & $0.50-1.46$ & 0.77 & $0.42-1.41$ & 0.96 & $0.56-1.65$ & 0.86 & $0.47-1.57$ \\
\hline Urban (ref) & 1 & - & 1 & - & 1 & - & 1 & - \\
\hline
\end{tabular}

$\mathrm{OR}$, odds ratio; ref, reference category; $\mathrm{Cl}$, confidence interval.

$*, p<0.05 ; * *, p<0.001$.

\section{Discussion}

Previous studies on tobacco use in South Africa focused on the general population without people with underlying mental illnesses, ${ }^{3,4,5}$ thus creating a gap in the overall understanding of tobacco use in the country.

As such, interventions aimed at tobacco use cessation tend to neglect individuals with mental illness. This study examined the prevalence of tobacco use (lifetime and current use) of individuals with mental illness in the Eastern Cape province. Tobacco use increases the risk of mental illnesses and directly interferes with the metabolism of certain psychotropic drugs, ${ }^{8,19}$ and therefore it deserves attention.

This study found a high prevalence of lifetime (54.9\%) and current tobacco use (44.6\%) amongst individuals with mental illness in the study cohort. These rates are higher than those found in the general population in the region $(15 \%)^{5}$ and the country (17.6\%). ${ }^{4}$ This finding corroborates other reports elsewhere in the world. In the United States of America, adults with mental illness smoked more in the previous month (33.3\%) than those without a mental illness (20.7\%). ${ }^{33}$ A similar pattern was reported in Brazil, with a current tobacco use prevalence of $53 \%$ in individuals with mental illness in comparison to $18 \%$ in the general population. ${ }^{34}$ Evidence suggests that despite a reduction in tobacco use in the general population in countries such as the United States of America, the United Kingdom and Australia, the prevalence of smoking amongst people with mental illness is two to three times that of the general population. ${ }^{10,35,36}$
Of interest in this population is the historical context of tobacco use within mental health facilities.

Tobacco products were used as rewards to reinforce desirable behaviours and in substance rehabilitation centres as an acceptable substitute for other substances. ${ }^{37}$ This may have further added to the burden created by tobacco use in an environment where individuals should be assisted with tobacco cessation. Most mental health facilities no longer permit smoking indoors, but some still operate partial smoke-free policies that allow inpatients to smoke outdoors. ${ }^{38}$ The movement towards the improvement of the health of individuals with mental illness by the establishment of completely smoke-free mental health facilities has gained traction over the years..$^{39}$

The present study found a significant association between patterns of tobacco use and the underlying mental illnesses in the cohort. Higher proportions of individuals with schizophrenia $(67.9 \%$ and $58.5 \%)$ and cannabis-related disorders (97.3\% and 86.7\%) reported lifetime and current tobacco use, respectively, in this study. However, fewer individuals with bipolar disorders (43.5\% and 27.5\%) and major depressive disorders (36.1\% and 25\%) reported lifetime and current tobacco use, with the difference being statistically significant.

These findings corroborate a previous report in the United States of America that found between $70 \%$ and $85 \%$ of individuals with schizophrenia smoked in comparison to $50 \%-70 \%$ with bipolar disorder. ${ }^{40}$ The National Institutes 
of Health panel observed that smoking prevalence was the highest amongst individuals with scizhophrenia (90\%) and that nicotine dependence was especially challenging for this group. ${ }^{41}$ Smokers with schizophrenia smoke more cigarettes and are more nicotine-dependent than the general population, ${ }^{42,43,44}$ and additionally had the highest rates of smoking in comparison with other mental illnesses. ${ }^{39}$ Despite the overwhelming evidence on the relationship between smoking and mental illness, there is a lack of tobacco cessation programmes targeting individuals with mental illness. This consequently may result in poorer health outcomes for the patients who are at increased risk of metabolic side effects of antipsychotics and mood stabilising drugs, in addition to the significant risk from tobacco use.

In this study, male individuals were six times more likely to report lifetime or current tobacco use than their female counterparts. This is similar to the findings in the same setting by Owolabi et al. ${ }^{5}$ albeit in the general population. Studies carried out in sub-Saharan Africa, the United States of America and Europe have also shown similar trends. ${ }^{34,45,46}$ However, reports from Sweden and Iceland showed equal use of tobacco products in both genders. ${ }^{46}$ The higher prevalence of men who use tobacco in this study and in South Africa in general can be ascribed to cultural and societal views where tobacco use is more acceptable amongst men than among women. ${ }^{47}$

Close relationships such as marriage or cohabitation have been shown to be beneficial in relation to lifestyle behaviours. ${ }^{48}$ Findings of this study showed that married or cohabiting people were twice as likely to smoke in comparison to single individuals. This is a surprising result, given that the opposite is true in the same setting amongst the general population. ${ }^{5}$ Several other studies have also reported contrasting results to the current study. ${ }^{49,50}$ However, all of these studies did not include individuals with mental illness. It is plausible in this population that a lack of insight, which is a feature of mental illness, may over-ride the protection offered by an intimate relationship. More studies of individuals with mental illness in the country will provide clarity on this association.

This study showed that individuals who were employed have higher odds of current tobacco use compared with those on government social grants. This result should be treated with caution, given the small number of individuals who were employed $(8.5 \%)$ in comparison to those unemployed $(81 \%)$. However, these results followed a similar pattern to the rest of the general population in the same setting. Owolabi et al. reported a prevalence of $21 \%$ and $14.1 \%$ amongst employed and unemployed adults, respectively, in the region. ${ }^{5}$

The prevalence of tobacco use in the present study is far higher for each category of tobacco use: $66.7 \%$ and $51.5 \%$ for lifetime use and current use amongst employed individuals in comparison with $55.7 \%$ and $45.9 \%$ amongst unemployed individuals with mental illness. Evidence points to an association between smoking and unemployment ${ }^{51}$; however, it is unclear whether smoking is a cause or effect of unemployment. $^{52}$ Many studies from Europe and New Zealand have reported contrasting results that showed higher rates of smoking in unemployed compared to employed individuals in the general population. ${ }^{53,54,55}$ In addition, Ham et al. found that the type of work in itself is a determinant of tobacco use; specifically, the blue-collar workers were more likely to start smoking cigarettes at a younger age and heavily than white-collar workers. ${ }^{56}$

In this study, individuals between the ages of 35 and 55 years were more likely to use tobacco in comparison to other age categories. A similar trend was reported by Owolabi et al., with the highest rate of smoking (19.2\%) observed between 46 and 55-year-olds in the general population. ${ }^{5}$ Champagne et al. reported a similar trend in Latin America, where the highest prevalence was in the age group of 35-44 years. ${ }^{57}$ This age group represents a significant percentage of working people. Therefore, it can be deduced that access to money made a difference in the pattern of tobacco use in this population.

\section{Strength and limitations}

Although this study was conducted in a single health facility centre, it should be noted that this hospital offers mental healthcare services to the entire BCMM and Amathole district of the Eastern Cape province, which has a combined population of 1674637 people living in the region. ${ }^{24}$ As such, this study highlights a very important public health issue in an often-neglected population. Findings of this study may be useful for health authorities and health in planning on how to improve the overall well-being of people with mental health problems in the region.

The cross-sectional design and the self-reporting of the main outcome measures are notable limitations of the study. As a result of the cross-sectional nature of this study, causal inference cannot be drawn. Also, if the attending doctor is administering the questionnaire, it could lead to reporting bias on tobacco use. However, this was mitigated by cross-checking the clinical notes and where there were discrepancies, the information in the clinical note was recorded in the questionnaire. Future studies in this population should assess nicotine dependence and further build on findings of the present study.

\section{Conclusion}

We found a high prevalence of tobacco use in the study sample, particularly amongst individuals who were married or in cohabiting relationship, employed and aged between 36 and 55 years. In addition, individuals with underlying schizophrenia and cannabis-related disorders were at higher risk of lifetime or current use of tobacco products. Therefore, mental health clinicians should design a screening tool for 
tobacco use in this population with a view to identify individuals for cessation interventions. Smoking cessation interventions for people with mental illness require targeted research in the country.

\section{Acknowledgements}

The authors are grateful to the staff (doctors and nurses) of the Cecila Makiwane Hospital Mental Health Department for their support towards the successful implementation of the study.

\section{Competing interests}

The authors declare that they have no financial or personal relationships that may have inappropriately influenced them in writing this article.

\section{Authors' contributions}

L.K.T. and O.V.A. conceptualised and designed the study protocol. L.K.T. implemented the project and drafted the article with O.V.A. Data analysis was conducted by A.I.A. who provided intellectual input to the draft of the article.

\section{Funding information}

The authors received no financial support for the research, authorship and/or publication of this article.

\section{Data availability}

Data for this project form part of the MMED research for L.K.T. Data included in this article are available from L.K.T. upon reasonable request.

\section{Disclaimer}

The views and opinions expressed in this article are those of the authors and do not reflect the official position or policy of any affiliated institutions of the authors.

\section{References}

1. World Health Organization. WHO report on the global tobacco epidemic, 2013: Enforcing bans on tobacco advertising, promotion and sponsorship [homepage on the Internet]. World Health Organization; 2013 [cited 2020 Sep 12]. Available from: https://apps.who.int/iris/bitstream/handle/10665/85381/WHO NMH PND_13.2_eng.pdf

2. World Health Organization. WHO global report on trends in tobacco smoking 2000-2025 [homepage on the Internet]. Geneva: World Health Organization; 2015 [cited 2020 Sep 12]. Available from: http://www.who.int/ Organization; 2015 [cited 2020 Sep 12]. Available from: http://www.who.int/ tobacco/pu
index4.html

3. National Department of Health (NDoH), Statistics South Africa (Stats SA), South African Medical Research Council (SAMRC), ICF. South Africa demographic and health survey 2016 [homepage on the Internet]. 2016 [cited 2020 Sep 22]. health survey 2016 [homepage on the Internet]. 2016 [cited 2020
Available from: https://dhsprogram.com/pubs/pdf/FR337/FR337.pdf

4. Reddy P, Zuma K, Shisana O, Jonas K, Sewpaul R. Prevalence of tobacco use among adults in South Africa: Results from the first South African National Health and Nutrition Examination Survey. S Afr Med J. 2015 Dec 9;105(8):648-655. https:// Nutrition Examination Survey. S
doi.org/10.7196/SAMJnew.7932

5. Owolabi EO, Goon DT, Adeniyi OV, Seekoe E, Adedokun AO. Prevalence and factors associated with tobacco use among adults attending selected healthcare facilities in Buffalo City Metropolitan Municipality, South Africa. S Afr Fam Pract. 2017;59(6):201-207. https://doi.org/10.1080/20786190.2017. Afr Fam 1340251
6. World Bank Group. Prevalence of current tobacco use (\% adults) [homepage on the Internet]. Rev ed. 2021 [cited 2021 Feb 6]. Available from https://data. worldbank.org/indicator/SH.PRV.SMOK

7. Gilbody S, Peckham E, Bailey D, et al. Smoking cessation for people with severe mental illness (SCIMITAR+): A pragmatic randomised controlled trial. Lancet Psychiatry. 2019 May 1;6(5):379-390.

8. Boksa P. Smoking, psychiatric illness and the brain. J Psychiatry Neurosci. 2017 May;42(3):147. https://doi.org/10.1503/jpn.170060

9. Pal A, Balhara YP. A review of impact of tobacco use on patients with co-occurring psychiatric disorders. Tob Use Insights. 2016 Jan;9:TUI-S32201. https://doi. org/10.4137/TUI.S32201

10. Prochaska JJ, Das S, Young-Wolff KC. Smoking, mental illness, and public health Annu Rev Public Health. 2017 Mar 20;38(1):165-185. https://doi.org/10.1146/ annurev-publhealth-031816-044618

11. Solmi $M$, Veronese $N$, Sergi $G$, et al. The association between smoking prevalence and eating disorders: A systematic review and meta-analysis. Addiction. 2016 Nov;111(11):1914-1922.

12. Windle $M$, Windle RC. Depressive symptoms and cigarette smoking among middle adolescents: Prospective associations and intrapersonal and interpersonal influences. J Consult Clin Psychol. 2001 Apr;69(2):215.

13. Baker TB, Piper ME, McCarthy DE, Majeskie MR, Fiore MC. Addiction motivation reformulated: An affective processing model of negative reinforcement. Psychol Rev. 2004 Jan;111(1):33.

14. Breslau N, Novak SP, Kessler RC. Daily smoking and the subsequent onset of psychiatric disorders. Psychol Med. 2004 Mar;34(2):323-333. https://doi. org/10.1017/S0033291703008869

15. Goodman E, Capitman J. Depressive symptoms and cigarette smoking among teens. Pediatrics. 2000 Oct 1;106(4):748-755. https://doi.org/10.1542/ peds.106.4.748

16. Kandel ER, Kandel DB. A molecular basis for nicotine as a gateway drug. $N$ Engl J Med. 2014 Sep 4;371(10):932-943.

17. Bandiera FC, Arheart KL, Caban-Martinez AJ, et al. Secondhand smoke exposure and depressive symptoms. Psychosom Med. 2010 Jan;72(1):68. https://doi. org/10.1542/peds.106.4.748

18. Bandiera FC, Richardson AK, Lee DJ, He JP, Merikangas KR. Secondhand smoke exposure and mental health among children and adolescents. Archiv Pediat Adolesc Med. 2011 Apr 4;165(4):332-338.

19. Ayano G. Psychotropic medications metabolized by cytochromes P450 (CYP1A2) enzyme and relevant drug interactions: Review of articles. Austin J Pharmaco Ther. 2016;4(2):2-5. https://doi.org/10.4172/2167-065X.1000162

20. Prochaska JJ. Smoking and mental illness - Breaking the link. N Engl J Med. 2011 Jul 21;365(3):196-198.

21. Ellingrod VL. Drug interactions with tobacco smoke: Implications for patient care. Curr Psychiatry. 2013 Jan;12(1):12-16.

22. Wijesundera $H$, Hanwella R, De Silva VA. Antipsychotic medication and tobacco use among outpatients with schizophrenia: A cross-sectional study. Ann Gen Psychiatry. 2014 Dec 1;13(1):7.

23. Lê Cook B, Wayne GF, Kafali EN, Liu Z, Shu C, Flores M. Trends in smoking among adults with mental illness and association between mental health treatment and smoking cessation. JAMA. 2014 Jan 8;311(2):172-182. https://doi.org/10.1001/ jama.2013.284985

24. Statistics South Africa. South African Statistics, 2011 [homepage on the Internet] 2011 [cited 2020 Sep 12]; p. 1-190. Available from: http://www.statssa.gov.za/ publications/SAStatistics/SAStatistics2011.pdf

25. Cochran WG. Sampling techniques. New York, NY: Wiley; 1977.

26. Weich L, Pienaar W. Occurrence of comorbid substance use disorders among acute psychiatric inpatients at Stikland Hospital in the Western Cape, South Africa. Afr J Psychiatry. 2009;12(3):213-217. https://doi.org/10.4314/ajpsy.v12i3.48496

27. American Psychiatric Association. Diagnostic and statistical manual of mental disorders Fifth edition (DSM-5). Arlinton, VA. American Psychiatric Association 2013.

28. World Health Organization. Distribution: General steps: A framework for surveillance The WHO STEPwise approach to Surveillance of noncommunicable diseases (STEPS) [homepage on the Internet]. Geneva: World Health Organization 2003 [cited 2019 Jul 2]. Available from: www.who.int/...surveillance/.../steps 2003 [cited 2019 Jul 2]

29. NIDA. Resource guide: Screening for drug use in general medical settings [homepage on the Internet]. 2012 [cited $2020 \mathrm{Sep} \mathrm{19].} \mathrm{Available} \mathrm{from:} \mathrm{https://}$
archives.drugabuse.gov/publications/resource-guide-screening-drug-use-inarchives.drugabuse.gov/p
general-medical-settings

30. Inoue-Choi M, Liao LM, Reyes-Guzman C, Hartge P, Caporaso N, Freedman ND. Association of long-term, low-intensity smoking with all-cause and causespecific mortality in the National Institutes of Health-AARP Diet and Health Study. JAMA Intern Med. 2017;177(1):87-95. https://doi.org/10.1001/ jamainternmed.2016.7511

31. Hackshaw A, Morris JK, Boniface S, Tang JL, Milenković D. Low cigarette consumption and risk of coronary heart disease and stroke: Meta-analysis of 141 cohort studies in 55 study reports. BMJ. 2018;360:j5855. https://doi.org/10.1136/ bmj.j5855

32. Geyer $S$, Hemström Ö, Peter R, Vågerö D. Education, income, and occupational class cannot be used interchangeably in social epidemiology. Empirical evidence against a common practice. J Epidemiol Community Health. 2006 Sep 1;60(9):804-810. https://doi.org/10.1136/jech.2005.041319 
33. Lipari RN, Van Horn S. Smoking and mental illness among adults in the United States. In: The CBHSO report 2017 Mar 30. Substance Abuse and Mental Health Services Administration (US); 2013.

34. Barros FC, Melo AP, Cournos F, Cherchiglia ML, Peixoto ER, Guimarães MD. Cigarette smoking among psychiatric patients in Brazil. Cad Saúde Pública. 2014;30(6):1195-206. https://doi.org/10.1590/0102-311X00027113

35. Gfroerer J, Dube SR, King BA, Garrett BE, Babb S, McAfee T. Vital signs: Current cigarette smoking among adults aged $\geq 18$ years with mental illness - United States, 2009-2011. MMWR Morb Mortal Wkly Rep. 2013 Feb 8;62(5):81.

36. Schroeder SA. Smoking cessation should be an integral part of serious mental illness treatment. World Psychiatry. 2016 Jun;15(2):175. https://doi.org/10.1002/ wps.20332

37. Johnson J. Tobacco control in the context of mental illness and addictions: Reviewing the evidence. Vis J. 2007;3(4):6-7.

38. Prochaska JJ, Hall SM, Bero LA. Tobacco use among individuals with schizophrenia: What role has the tobacco industry played? Schizophr Bull. 2008 May 1;34(3):555-567.

39. Stockings EA, Bowman JA, Baker AL, et al. Impact of a postdischarge smoking cessation intervention for smokers admitted to an inpatient psychiatric facility: $A$ randomized controlled trial. Nicotine Tob Res. 2014 Nov 1;16(11):1417-1428. https://doi.org/10.1002/wps.20332

40. NIDA. Do people with mental illness and substance use disorders use tobacco more often? National Institute on Drug Abuse website [homepage on the Internet]. 2020 [cited 2020 Sep 10]. Available from: https://www. drugabuse.gov/publications/research-reports/tobacco-nicotine-e-cigarettes/ do-people-mental-illness-substance-use-disorders-use-tobacco-more-often

41. NIH State of the Science Panel. National Institutes of Health State of the Science conference statement: Tobacco use: Prevention, cessation, and control. Ann Intern Med. 2006;145(11):839-844. https://doi.org/10.7326/0003-4819-145-11 200612050-00141

42. AhnAllen CG, Liverant Gl, Gregor KL, et al. The relationship between rewardbased learning and nicotine dependence in smokers with schizophrenia. Psychiatry Res. 2012 Mar 30;196(1):9-14.

43. Šagud M, Vuksan-Ćusa B, Jakšić N, et al. Nicotine dependence in Croatian male inpatients with schizophrenia. BMC Psychiatry. 2018 Dec 1;18(1):18. https://doi. org/10.1186/s12888-018-1606-

44. Ohi K, Shimada T, Kuwata A, et al. Smoking rates and number of cigarettes smoked per day in schizophrenia: A large cohort meta-analysis in a Japanese population. Int J Neuropsychopharmacol. 2019 Jan;22(1):19-27.

45. Sreeramareddy CT, Pradhan PM, Sin S. Prevalence, distribution, and social determinants of tobacco use in 30 sub-Saharan African countries. BMC Med. 2014 Dec 1;12(1):243. https://doi.org/10.1186/s12916-014-0243-x
46. OECD/European Union. Smoking among adults. In: Health at a glance: Europe 2018: State of Health in the EU Cycle [homepage on the Internet]. Paris: OECD Publishing; 2018 [cited 2020 Sep 22]. Available from: https://www.oecdOECD Publishing; 2018 [cited 2020 Sep 22]. Available from: https://www.oecd-
ilibrary.org/social-issues-migration-health/health-at-a-glance-europe-2018/ smokingamong-adults_health_glance_eur-2018-21-en.

47. Reddy PD, James S, Sewpaul R, et al. A decade of tobacco control: The South African case of politics, health policy, health promotion and behaviour change. S Afr Med J. 2013 Oct 25;103(11):835-840.

48. Umberson D, Crosnoe R, Reczek C. Social relationships and health behavior across the life course. Annu Rev Sociol. 2010 Aug 11;36(1):139-157. https://doi. org/10.1146/annurev-soc-070308-120011

49. Movsisyan NK, Sochor O, Kralikova E, Cifkova R, Ross H, Lopez-Jimenez F. Current and past smoking patterns in a Central European urban population: A crosssectional study in a high-burden country. BMC Public Health. 2016 Dec 1;16(1):571. https://doi.org/10.1186/s12889-016-3216-5

50. Phillips E, Wang TW, Husten CG, et al. Tobacco product use among adults - United States, 2015. MMWR Morb Mortal Wkly Rep. 2017 Nov 10;66(44):1209. https:// doi.org/10.15585/mmwr.mm6644a2

51. Castaldelli-Maia JM, Masters N. The relationship between smoking and unemployment: New avenues for interdisciplinary research. Int J Soc Psychiatry. 2015 Sep 1;61(6):613-614.

52. Prochaska JJ, Michalek AK, Brown-Johnson C, et al. Likelihood of unemployed smokers vs nonsmokers attaining reemployment in a one-year observational study. JAMA Intern Med. 2016 May 1:176(5):662-670. https://doi.org/10.1001/ jamainternmed.2016.0772

53. Okechukwu C, Bacic J, Cheng KW, Catalano R. Smoking among construction workers: The nonlinear influence of the economy cigarette prices, and antismoking sentiment. Soc Sci Med. 2012 Oct 1;75(8):1379-1386. https://doi. org/10.1016/j.socscimed.2012.05.035

54. Rizov M, Herzfeld T, Huffman SK. The Russian food, alcohol and tobacco consumption patterns during transition. Coll Antropol. 2012 Dec 27;36(4):1143-1154.

55. Kaleta D, Makowiec-Dabrowska T, Dziankowska-Zaborszczyk E, Fronczak A Predictors of smoking initiation - Results from the Global Adult Tobacco Survey (GATS) in Poland 2009-2010. Ann Agric Environ Med. 2013;20(4):756-766. https://doi.org/10.1016/j.socscimed.2012.05.035

56. Ham DC, Przybeck T, Strickland JR, Luke DA, Bierut LJ, Evanoff BA. Occupation and workplace policies predict smoking behaviors: Analysis of national data from the current population survey. J Occup Environ Med. 2011 Nov;53(11):1337. https:// doi.org/10.1097/JOM.0b013e3182337778

57. Champagne BM, Sebrié EM, Schargrodsky $H$, Pramparo $P$, Boissonnet $C$, Wilson $E$. Tobacco smoking in seven Latin American cities: The CARMELA study. Tob Control. 2010 Dec 1;19(6):457-462. https://doi.org/10.1136/tc.2009.031666 